\author{
Mirjana M. Knežević \\ University of Belgrade ${ }^{* * *}$ \\ Faculty of Philology \\ Belgrade, Serbia
}

\title{
POSTMODERN IRONY AND HUMOR IN CATCH-22 BY JOSEPH HELLER AND THEIR PARALLELS IN POSTMODERN MUSIC AND ART
}

\begin{abstract}
This essay explores the concept of irony and the ways in which this mode is reflected in such distant forms of aesthetic expression as literature, music and visual arts, especially within the postmodern era which not only embraces, but also intensifies and influences this long-established stylistic technique. With this aim, this essay takes Joseph Heller's novel Catch-22 as a representative example of the postmodern literature, as well as Kurt Vonnegut's graphic Trout in Cohoes, Rupert Holms's The Pina Colada Song and Leroy Anderson's The Waltzing Cat as corresponding examples of postmodern visual and music arts respectively. The theoretical framework is based on Wayne Booth's concept of irony, and also includes humor as an accompanying element of ironic expression.
\end{abstract}

Key words: irony, humor, postmodernism, Joseph Heller, Catch-22, Wayne Booth

E-mail address for correspondence: pubebe@sezampro.rs

** $\mathrm{PhD}$ candidate 


\section{Introduction: from Plato to postmodernism}

"The only shield against irony, therefore, is absolute circumspection, a shield no man can lift."

(Muecke 1969: 31)

Asked to define irony, many a person will face a difficult but challenging task, since continuing disagreements among critics, despite the concept's long history, add to the complexity and elusiveness of the term. As a mode of expressing a certain discrepancy or incongruity between words or situations and their meanings, the term irony derives from the Greek 'eiron', a common character in Greek comedy, who pretends to be foolish and ignorant, and whose modesty of speech contrasts with another common, though pretentious character called 'alazon'.

As a literary technique, irony was first recorded in the Platonic dialogues where Socrates assumes the role of the eiron, and by asking seemingly innocuous and naive questions exposes the self-contradictions of his conversers, forcing them into seeing the truth. Nowadays, this technique is commonly known as Socratic irony. For the Roman rhetoricians irony was a rhetorical figure that expressed a meaning contrary to the literal meaning of the words. "This double-edgedness appears to be a diachronic feature of irony." (Cuddon 1999: 427-428)

At the turn of the 18th century, Friedrich Schlegel pointed out the ironical nature of the balance maintained between the serious and the comic. He also used the term irony "in connection with the detached and objective viewpoint of the artist and his work" (Cuddon 1999: 429), creating the concept of 'romantic irony'.

Before the eighteenth century, irony was one rhetorical device among many, the least important of the rhetorical tropes. By the end of the Romantic period, it had become a grand Hegelian concept, with its own essence and necessities; or a synonym for romanticism; or even an essential attribute of God. And in our century it became a distinguishing mark of all literature, or at least all good literature. (...) [A]ll of these refer, in life and literature, to the ways in which, for those who can tell a hawk from a handsaw, the hawk's view modifies or "discounts" the handsaw's, and vice versa.

(Booth 1974: ix) 
Mirjana M. Knežević Postmodern irony and humor in Catch-22 by Joseph Heller and their ...

Irony has numerous functions: it clarifies and intensifies the reader's notions and perceptions of the author's intentions and the truth of the work. This is what Northrop Frye says about irony in Anatomy of Criticism:

The ironic fiction-writer, then, deprecates himself and, like Socrates, pretends to know nothing, even that he is ironic. Complete objectivity and suppression of all explicit moral judgments are essential to his method. Thus pity and fear are not raised in ironic art: they are reflected to the reader from the art. When we try to isolate the ironic as such, we find that it seems to be simply the attitude of the poet as such, a dispassionate construction of a literary form, with all assertive elements, implied or expressed, eliminated. Irony, as a mode, is born from the low mimetic; it takes life exactly as it finds it. But the ironist fables without moralizing, and has no object but his subject. Irony is naturally a sophisticated mode....

(Frye 1957: 40-41)

We may conclude that irony is not a new postmodern technique, but continues and often intensifies the ironic literary technique of the previous periods. Since it questions the surface intentions of the work, it is not surprising that, in the postmodern era, with its denial of absolute knowledge and the accompanying idea of multiple truths, it has become one of the most important devices of the author's style.

\section{Wayne Booth: marks of irony and the steps in its reconstruction}

Regardless of inconsistent theoretical definitions, all types of irony, according to American literary critic Wayne Booth (and his canonic work A Rhetoric of Irony, 1974), share four marks of irony: first, "they are all intended, deliberately created by human beings to be heard or read and understood with some precision by other human beings" (Booth 1974: 5); second, "they are all covert, intended to be reconstructed with meanings different from those on the surface" (Booth 1974: 6), in contrast to overt or direct assertions; next, "they are all nevertheless stable or fixed, in the sense that once a reconstruction of meaning has been made, the reader is not then invited to undermine it with further demolitions and reconstructions" 
(Booth 1974: 6); and, finally, "they are all finite in application" (Booth 1974: 6), in contrast to infinite, either stable or unstable, ironies.

According to Booth's theory, there are four steps in reconstructing these unspoken meanings whereby the author says one thing but intends another, inviting the reader to trace the hidden messages. In step one, since the reader recognizes certain incongruity between the words and their meanings, he "is required to reject the literal meaning" (Booth 1974: 7). In step two, "alternative interpretations or explanations are tried out" (Booth 1974: 7), such as that the author himself is for some reason unaware of this discrepancy. In step three, the reader must come to a conclusion about the author's knowledge or beliefs. The reader's confidence that the author is being ironic depends on his conviction that, like him, the author sees and rejects what the statement implies. "It is this decision about the author's own beliefs that entwines the interpretation of stable ironies so inescapably in intentions." (Booth 1974: 11) No matter how convinced the reader is that a statement is illogical, he must determine whether what he rejects is also rejected by the author, and whether there is a basis for the author to expect the reader's agreement. The author thus becomes "only the creative person responsible for the choices that made the work - what I have elsewhere called the 'implied author' who is found in the work itself" (Booth 1974: 11). In step four, after we have come to a conclusion about the knowledge or beliefs of the author, we are invited to choose a new meaning. "Unlike the original proposition, the reconstructed meanings will necessarily be in harmony with the unspoken beliefs" (Booth 1974: 12) that the reader has decided to attribute to the author.

\section{Irony and humor in postmodern arts: a comparative analysis}

"The postmodern reply to the modern consists of recognizing that the past, since it cannot really be destroyed, because its destruction leads to silence, must be revisited: but with irony, not innocently."

(Eco 1985: 7) 
Mirjana M. Knežević Postmodern irony and humor in Catch-22 by Joseph Heller and their ...

\section{Catch-22 by Joseph Heller: clues to irony}

The main theme of Joseph Heller's Catch-22 (1961) is the irony of the now-idiomatic 'catch-22', but the narrative is also structured around the motif of bureaucratic absurdity and a prolonged series of similar ironies.

The novel's protagonist is Yossarian, a U.S. Army Air Force bombardier, stationed during World War II on a Mediterranean island near Italy, but the narrative also follows a number of other characters describing, in a non-chronological style, the events from their different points of view. Yossarian's antiwar and anti-heroic comments provide ironical and humorous counterpoint to the tragedy of the war. The irony of the novel thus involves the use of the protagonist whose view of the world questions the views of other characters and, by implication, of the implied author.

And there is much more irony in the novel: in addition to the numerous examples of direct or overt irony that we find in the work of this author, we also find a continuous thread of an ironic temper or tone, an ironic way of looking at things, a spirit of irony which prevails in Heller's work.

According to Booth's theory, there are several clues to detecting and reconstructing the ironic meanings of literary texts: straightforward warnings, known error proclaimed, conflicts of facts within the work, clashes of style, and conflicts of belief.

\section{a) Straightforward clues to irony}

Following Booth's theory, direct guidance from the author or straightforward warnings of irony "in the author's own voice" (Booth 1974: 53) include warnings in the title, in epigraphs, and other direct clues, such as prefaces and postscripts. The clues traceable in the work in question include warnings in the novel's title, epigraph and preface.

Warnings in the title. This is a form of the author's straightforward warning where he uses the title of the novel to signal the ironic quality of the entire work. The title gives us "quite directly information that we can immediately use in suspecting 'secret' intentions behind the narrator's words" (Booth 1974: 53).

'Catch-22' from the novel's title, as a reference to a fictional bureaucratic stipulation, bears an ironic overtone in its being a catch codified with a number, which indicates further bureaucratic nonsense 
and absurdities in the story, including multiple forms of unreasonable and immoral deductions.

This is how the military police ironically explain 'catch-22': "Catch-22 states that agents enforcing Catch-22 need not prove that Catch-22 actually contains whatever provision the accused violator is accused of violating" (Heller 1961: 139). Also, another provision states: "Catch-22 says they have a right to do anything we can't stop them from doing" (Heller 1961: 147). The irony of the eponymous 'catch-22', a recurring motif in the story, thus presents the main theme of the novel.

Warnings in epigraph. The novel begins with an epigraph, which is another clue to its ironic intentions: "This island of Pianosa lies in the Mediterranean Sea eight miles south of Elba. It is very small and obviously could not accommodate all of the actions described. Like the setting of this novel, the characters, too, are fictitious." (Heller 1961) There is a twofold manifestation of straightforward warnings of irony within this epigraph. First, in line with the concept of romantic irony, it consciously undermines the novel's fictional illusion by exposing the process of composition "as a matter of authorial whim" (Baldick 1996: 222). Second, the epigraph also introduces the ironic tone by paradoxically stating that the island is too small to accommodate all the actions that take place there.

The author never appears again in the novel directly; having informed the reader of the fictitious nature of both the setting and the characters in the novel, and having also ironically suggested the multitude of actions performed on this nonexistent, yet too small an island, "he then left them to speak entirely for themselves. Or rather one should say that he pretended to. Every word chosen spoke for him, but not directly." (Booth 1974: 55)

Other direct clues. The most apparent warning of all, according to Booth, is a direct statement by the author, such as in prefaces and postscripts.

In his Preface to the 1994 Edition of Catch-22 Joseph Heller wrote:

But Yossarian is alive when the novel ends. Because of the motion picture, even close readers of the novel have a final, lasting image of him at sea, paddling toward freedom in a yellow inflated lifeboat. In the book he doesn't get that far; but he is not captured and he isn't dead. (...) Sooner or later, I must concede, 
Mirjana M. Knežević Postmodern irony and humor in Catch-22 by Joseph Heller and their ...

Yossarian, now seventy, will have to pass away too. But it won't be by my hand.

(Heller 1994)

The author conveys his ironic tone and attitude by commenting on the character, thus being critically aware of the literary composition he is creating (which is sometimes referred to as a 'literary self-consciousness' of the ironic work).

But these straightforward warnings are only an opening clue in a long series of clues that secure an ironic tone in the novel.

In short, if we look at the first kind of clue, the author's direct statement in title, epigraph, postscript, or whatever, and ask how we know that the author speaks to us in a more direct tone in them than in his other words, we discover that the direct statement is always at best only a hint; our confidence begins to rise only when we come to other clues. Unless what the voice says or does conflicts in some clear way with what we can be sure the author would say, we will not know that the passage is ironic.

(Booth 1974: 57)

The other clues include known error proclaimed, conflicts of facts within the work, clashes or disharmonies of style and conflicts of belief.

\section{b) Known error proclaimed}

Clues to irony referred to by Booth as 'known error proclaimed' or 'deliberate error' include, in the novel which is the subject of our analysis, popular expressions and conventional judgment clues.

Popular expressions. "He was a self-made man who owed his lack of success to nobody" (Heller 1961: 13), says the narrator describing one of the characters. Taken by itself the confusion of the statement with the common "He was a self-made man who owed his success to nobody" might mean that the narrator is himself "ignorant of the standard expressions: not ironic, just ignorant. But in a context of other 'incredible' errors, probabilities become certainties: [the author is] communicating with us from behind [his] narrators' backs". (Booth 1974: 58) 
There is, moreover, a dialogue based on discussing an ironically reversed saying and its possible meanings:

'Because it's better to die on one's feet than live on one's knees,' Nately retorted with triumphant and lofty conviction. 'I guess you've heard that saying before.' 'Yes, I certainly have,' mused the treacherous old man, smiling again. 'But I'm afraid you have it backward. It is better to live on one's feet than die on one's knees. That is the way the saying goes.' 'Are you sure?' Nately asked with sober confusion. 'It seems to make more sense my way.' 'No, it makes more sense my way. Ask your friends.'

(Heller 1961: 135)

Another such 'error' is a negative reversal of another popular expression: "It takes brains not to make money" (Ibid: 18), producing an ironic commentary on the character referred to and the practice of wartime profit making, another engaging theme in the novel.

Conventional judgment. "Major Major had been born too late and too mediocre. Some men are born mediocre, some men achieve mediocrity, and some men have mediocrity thrust upon them. With Major Major it had been all three. Even among men lacking all distinction he inevitably stood out as a man lacking more distinction than all the rest, and people who met him were always impressed by how unimpressive he was." (Ibid: 44) In this passage, when Heller speaks of the character 'achieving mediocrity' or 'standing out as a man lacking more distinction than all the rest', we do not encounter vocabulary inaccuracy in applying the verbs 'achieve' and 'stand out' to negative qualities, but a call to the reader's judgment of the author's ironic intentions of the text.

In "Men went mad and were rewarded with medals" (Ibid: 7), the point of the latter half of the statement depends on the reader's knowledge of conventional notions of valid judgment, whereby men who go mad are not normally rewarded with medals.

A short dialogue with the protagonist: '“How is Lieutenant Dunbar?' he asked at last. 'As good as they go,' Yossarian assured him. 'A true prince. One of the finest, least dedicated men in the whole world"' (Ibid: 6) stands as a valid example of antiphrasis, a figure of speech very common to this type of ironic clue, which uses a word or a phrase ('a true prince', in this case) in a sense directly opposite to its usual meaning, showing the way in which the meaning of a statement can be completely reversed by 
Mirjana M. Knežević Postmodern irony and humor in Catch-22 by Joseph Heller and their ...

a knowledge of its context (lieutenant - 'the least dedicated men in the whole world').

These are all "deliberate factual discords" (Booth 1974: 61), deliberate ironic under- or over-statements. All these examples lead us to treat possible incongruities within the text that oppose our knowledge or conventional judgments not as casual inaccuracies, omissions or ignorance on the part of the author, but as deliberate errors pointing to a wider sense of inescapable irony.

\section{c) Conflicts of facts within the work}

This clue to the author's ironic intentions corresponds to another quality inherent in the nature of irony, the element of the absurd and the paradoxical. A good example in the novel is the paradoxical situation with Catch-22 specifying that only soldiers who are crazy can be grounded, but, if they ask to be grounded, they will no longer be treated as crazy and will have to fly more missions:

Orr would be crazy to fly more missions and sane if he didn't, but if he was sane he had to fly them. If he flew them he was crazy and didn't have to; but if he didn't want to he was sane and had to. Yossarian was moved very deeply by the absolute simplicity of this clause of Catch-22 and let out a respectful whistle.

(Heller 1961: 23-4)

The reader's consequent conclusions about what in fact is going on is exactly the reverse of what the literal meaning intends, and the impossibility of the reader's 'believing' what the passage actually 'says' reveals the sense of irony.

"That crazy bastard may be the only sane one left" (Ibid: 60) and "Under Colonel Korn's rule, the only people permitted to ask questions were those who never did" (Ibid: 18) are some other examples of contradictory statements where the "false" voice must be "repudiated" and the "correct" voice must "triumph" producing "the reverse of 'advance warning"' (Booth 1974: 61). Some other examples include: "The dead man in Yossarian's tent was simply not easy to live with" (Heller 1961: 10), illustrating paradoxical discrepancy between words and their meaning, and "The Texan turned out to be good-natured, generous and likable. In three days no one could stand 
him" (Ibid: 3), exemplifying an absurd incongruity between actions and their results.

A further example is the conflict of facts that, on the one hand, the official enemies in the novel are the Germans, while, on the other, no Germans ever appear in the story as enemy combatants, except as pilots employed by a private entrepreneur working for the United States military units. Thus the reader becomes aware of a situational discrepancy between appearance and reality.

" $[\mathrm{M}]$ any works of stable irony provide within themselves the knowledge necessary for establishing that a speaker's ignorance is not shared by the author. Whenever a story, play, poem, or essay reveals what we accept as a fact and then contradicts it, we have only two possibilities. Either the author has been careless or he has presented us with an inescapable ironic invitation." (Booth 1974: 61)

\section{d) Clashes or disharmonies of style}

"If a speaker's style departs notably from whatever the reader considers the normal way of saying a thing, or the way normal for this speaker, the reader may suspect irony." (Ibid: 67) Postmodern ironists have specialized in such stylistic shifts.

"Bills piled up rapidly, and he was soon faced with the loss of his most precious medical instruments: his adding machine was repossessed, and then his typewriter. The goldfish died. Fortunately, just when things were blackest, the war broke out." (Heller 1961: 20) The melancholic tone of the first two sentences is followed by the lively rhythm of the third one and the use of the incongruous linking word 'fortunately'. The fact "that the passage is ironic is unmistakably revealed through violations of stylistic norms" (Booth 1974: 70) that the reader shares with the author.

"Milo's eyes were liquid with integrity, and his artless and uncorrupted face was lustrous with a shining mixture of sweat and insect repellent" (Heller 1961: 140-1) is another example of the conflict in stylistic levels. There is simply no way of reconciling the description of Milo's 'artless and uncorrupted' face and his eyes 'liquid with integrity' with the 'shining mixture of sweat and insect repellent', i.e., the somber author of the former part of the sentence with the humorous, sardonic author of the latter.

The stylistic clash is 
Mirjana M. Knežević Postmodern irony and humor in Catch-22 by Joseph Heller and their ...

based on recognizing different ways of saying what, in substance, would seem to amount to identical messages. Whenever, in the normal course of perusing a piece of precisely executed writing, whether discursive or imaginative, whether prose or verse, one encounters any radical tergiversation from those perhaps ineluctable norms of expression with which one is accustomed, one should promptly recognize that there is a strong likelihood that irony is being adumbrated.

(Booth 1974: 68)

A widespread form of ironic disharmonies of style, according to Booth, is what is commonly referred to as parody. In the words of this author, "[t] he most obvious use of stylistic clues in stable irony is found in parody, the mocking imitation by one author of another author's style" (Ibid: 71). Though parody is not commonly considered as 'irony', it is ironic in Booth's definition: the surface meaning must be rejected, and another, 'higher' meaning must be found by reconstruction.

In the work in question in our analysis, parody is revealed through style. It is revealed in the paragraph about a soldier called Milo, with direct associations, in its images of spring and lilacs, with T. S. Eliot's poem The Waste Land:

April had been the best month of all for Milo. Lilacs bloomed in April and fruit ripened on the vine. Heartbeats quickened and old appetites were renewed. In April a livelier iris gleamed upon the burnished dove. April was spring, and in the spring Milo Minderbinder's fancy had lightly turned to thoughts of tangerines.

(Heller 1961: 258)

This overt parallel to Eliot's work, referring readers to other meanings of the text, prepares them for the many ways in which the author places the description of his characters into an ironic shade.

\section{e) Conflicts of belief}

"Finally, we are alerted whenever we notice an unmistakable conflict between the beliefs expressed and the beliefs we hold and suspect the 
author of holding. We can see the resulting ironies most clearly when there is an incredible passage in the midst of straightforward writing." (Booth 1974: 73)

One of the indicators to such clues is illogicality: "He got on well with his brothers and sisters, and he did not hate his mother and father, even though they had both been very good to him." (Heller 1961: 136) We all know, or should know, what is 'logical', so it is obvious that the author pretends to be making certain statements which imply beliefs that he cannot have held. "Yossarian had everything he wanted in the hospital" (Heller 1961: 2 ) is another example of the author's manipulations and the violation of normal reasoning processes. This deliberate illogicality should be viewed as the author's invitation to join him in condemning the absurdity of things.

\section{Elements of humor}

"Perhaps the most original and important critic of our time, Kenneth Burke, has made irony into a kind of synonym for comedy." (Booth 1974: ix) This is also in line with the concept of romantic irony whereby irony involves "a playful attitude towards the conventions of the (normally narrative) genre." (Baldick 1996: 222)

Indeed, much of the use of irony in the work of Joseph Heller (who was initially called a black humorist, and only later labeled postmodernist) is colored toward comic effects. In addition to being illustrative of irony, his novel Catch-22 also provides a good example of humor, black (or dark) humor notably, since it includes playfulness in a plot with an otherwise humorless subject. The prevailingly tragic themes, such as the Second World War, battle injuries and death are for the most part treated humorously.

Comic relief can often intensify the irony of a situation, with ordinary characters and situations exaggerated beyond the limits of 'normal' irony: "Dunbar was lying motionless on his back again with his eyes staring up at the ceiling like a doll's. He was working hard at increasing his life span. He did it by cultivating boredom. Dunbar was working so hard at increasing his life span that Yossarian thought he was dead." (Heller 1961: 3) The element of humor in the novel includes puns: "Yossarian - the very sight of the name made him shudder. There were so many esses in it." (Heller 1961: 115)

The events in the novel are also described in the way that the new information often completes a joke commenced earlier, in a previous 
Mirjana M. Knežević Postmodern irony and humor in Catch-22 by Joseph Heller and their ...

chapter sometimes. For example, Chapter 1 ends with "In less than ten days, the Texan drove everybody in the ward back to duty-everybody but the C.I.D. man, who had caught cold from the fighter captain and come down with pneumonia" (Heller 1961: 7). Chapter 2 begins with "In a way the CID man was pretty lucky, because outside the hospital the war was still going on" (Heller 1961: 7), completing the joke from the previous chapter.

Another characteristic producing comic effect is the repetition of certain words and phrases, such as the use of the adjective 'crazy': "McWatt was crazy. He was a pilot and flew his plane as low as he dared over Yossarian's tent as often as he could, just to see how much he could frighten him. (...) Sharing a tent with a man who was crazy wasn't easy, but Nately didn't care. He was crazy, too, and had gone every free day to work on the officers' club that Yossarian had not helped build." (Heller 1961: 8) This humorous repetition questions the sanity of all the characters in the novel and, in a wider context, the purpose and justifiability of the war driving people insane.

This continual breaking of the serious tone, which points to the author's full awareness of the ambivalent nature of the novel, in line with the romantic concept, is another characteristic of irony:

The writer who employs what is called romantic irony (a concept for which Schlegel was largely responsible) exhibits true presence of mind by showing an awareness, a sensibility, that he does not expect his work to be taken wholly seriously - and does not wish it to be. He conveys this tone and attitude (thus inviting a complementary tone and attitude in his reader) by being at once critically aware of what he is doing and why he is doing it, even while he may be impelled by a strong dynamic creative purpose. Thus he is fully conscious of the comic implication of his own seriousness.

(Cuddon 1999: 767)

These are just some of the numerous manifestations of humor, black humor admittedly, in the novel. The continual playful tone produces a gradual and cumulative sense of irony, affirming it as a subtly humorous perception of the novel's inconsistency. The narrative thus involves some of the "key attributes of postmodernism", such as "its knowing irony" and "its playful polysemy or plurality of sense" (Sim 2001: 237). Playfulness and black humor, which both rely on Jacques Derrida's concept of 'play' and the 
ideas proposed by Roland Barthes in The Pleasure of the Text, together with the concept of irony, thus become some of the most discernible aspects of postmodernism.

\section{Parallels in music and visual art}

Postmodernism in music, as the postmodernist movement in general, is regarded as having developed as either a reaction to, or a continuation of certain aspects of modernism (for most authors, such as music theorists Leonard B. Meyer and Otto Karolyi, postmodern music originated at about 1930). It therefore shares characteristics with other postmodern arts, including, as such, irony and humor.

Jonathan Kramer, American composer and music theorist, following the theoretical concepts of Umberto Eco and Jean-François Lyotard, postulates the idea that postmodernism (including musical postmodernism) is "more an attitude than a historical period" (Kramer 2002: 216). He defines 16 characteristics of postmodern music, including a distinction that postmodern music "is not simply a repudiation of modernism or its continuation, but has aspects of both a break and an extension, [and] is, on some level and in some way, ironic" (Kramer 2002: 216).

Similar to literary irony, irony in music can involve both irony of situation and verbal irony, arising from a sophisticated awareness of contrast between what is and what appears to be. Escape, later known as Escape (The Piña Colada Song) (1979), a popular culture song written by an American-British composer, Rupert Holmes, is a good example of situational irony. It is a simple and light musical work in soft rock genre, whose lyrics speak of a man who, tired of his current relationship, decides to answer an ad of a woman who is seeking a man who must like piña coladas, getting caught in the rain, and some other little things. However, at the meeting, he finds out that the woman is actually his current girlfriend, and only then does he realize that she loves the same things as he does. Ironically, the two of them recognize through this strange situation that they do not have to search any further for what they seek in a relationship.

There is also some irony in the fact that, despite a variety of his other, more serious musical works (including his 1985 Tony 
Mirjana M. Knežević Postmodern irony and humor in Catch-22 by Joseph Heller and their ...

Award-winning musical Drood), as well as his literary achievements (in addition to being a songwriter, he was also the author of plays, novels and stories, and he won the 2007 Drama Desk Award for the Broadway musical Curtains), Holmes will remain remembered as the author of this amusing, unpretentious pop hit.

The Waltzing Cat (1950) by Leroy Anderson, American composer, illustrates the element of humor as used in postmodern music. It is a short, light concert piece, with creative instrumental effects, turning sentimental string sounds that are characteristic of Strauss waltzes into cats' meows.

Postmodernism in the visual arts emerged even earlier (in relation to Europe, at least) than in literature or music: most critics place the shift from modern to postmodern art at the beginning of World War I, precisely 1914 (McEvilly 1998: 27) in Europe, and the 1960s (Ibid: 29) in America.

Although irony is often defined as a language device, it is also a central feature in many works of postmodern visual art, where meaning is challenged not by the literal meanings of the words, but by the non-verbal meanings of the situation which contains certain incongruities between appearance and reality.

Kurt Vonnegut was not only an American novelist whose narrative works blended different genres such as black comedy and science fiction (such as his famous Slaughterhouse-Five), but he was also known in the domain of graphic art, blending, again, various modes of expression, including irony, playfulness and black comedy. In one of his numerous witticisms, this is how he commented on his own humorousness: "Laughter and tears are both responses to frustration and exhaustion... I myself prefer to laugh, since there is less cleaning up to do afterward" (Vonnegut 2009).

Trout in Cohoes is a graphic portrait of Vonnegut's fictional character, Kilgore Trout, who is also literarily portrayed in several novels by the author. His eleven eyes "tend to give the impression of a vibrating head, which certainly reflects Trout's constantly agitated state of mind. The birdcage in the background is the home of Trout's parakeet, Bill. In Breakfast of Champions Trout offers Bill three wishes and the chance of freedom. The wise bird returns to his cage, which Trout calls the smartest choice of all because then Bill will always have something left to wish for." (Reed 1999: 18) 


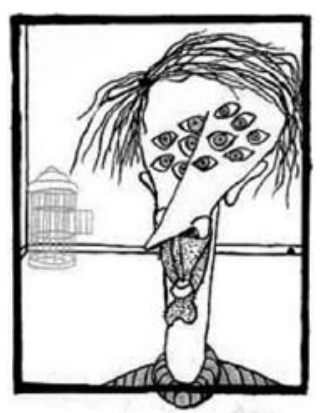

Kurt Vonnegut, Trout in Cohoes, 1997.

David Minton, a reviewer, wrote that "the portrait of Kilgore Trout possesses all the clear and open wit and humor (black humor admittedly) one finds in [Vonnegut's] novels" (Reed 1999: 18). When a university rejected his master's thesis in anthropology, Kurt Vonnegut commented: "It was rejected because it was so simple and looked like too much fun. One must not be too playful." (Vonnegut 1999: 267) In view of this anecdote it is not difficult to agree with American critic Peter Reed in his observation that "Vonnegut's curious blend of science fiction, black humor, absurdity, and relentless irony may be viewed as his way of dealing with an incomprehensible world" (Reed 1999: 19).

Vonnegut's graphic thus very well reflects the postmodern ironic and playful setting. The sense of irony contained in his versatile opus culminates perhaps in a tombstone graphic that appears in his famous work Slaughterhouse-Five, most ironically expressing the painful experience of World War II:

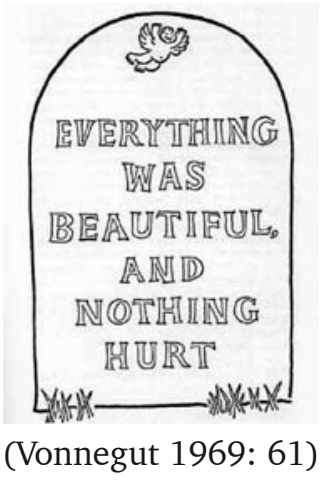


Mirjana M. Knežević Postmodern irony and humor in Catch-22 by Joseph Heller and their ...

This inscription on a tombstone, producing an image of life simultaneously lovely and painful, conveys, as do so many other postmodern works of the literary, musical and visual arts, a marvelous message of the beauty and irony of life.

\section{Conclusion}

"Perhaps it was our common sense of fun that first brought about our understanding. The real marriage of true minds is for any two people to possess a sense of humor or irony pitched in exactly the same key, so that their joint glances at any subject cross like interarching search-lights."

(Edith Wharton, talking of her growing friendship with Henry James, in A Backward Glance 1972: 173)

In accordance with Booth's theory, all the above analyzed works of postmodern art share the four established marks of irony: they are all intended ironies, deliberately created by their authors to be understood by the readers; they are all covert, designated to have their meanings construed as different from those on the surface; they are all stable, in the sense that we are not invited to undermine once made reconstructions of meaning; and last but not least, they are all finite in application. Their reconstruction, also, follows the four steps that can always, according to Booth, be discovered in the analysis of irony: rejecting the surface, literal meaning, trying out alternative interpretations, making a decision about the author's knowledge and beliefs, and finally constructing a meaning in harmony with that decision.

The artist becomes a kind of god viewing creation (and viewing his own creation) with a smile. From this it is a short step to the idea that God himself is the supreme ironist, watching the antics of human beings (Flaubert referred to a 'blague superieure') with a detached, ironical smile. The spectator in the theatre is in a similar position. Thus the everlasting human condition is regarded as potentially absurd. (...) In fact [Thomas] Mann, expert on the ironical, when speaking of the novel (in Die Kunst des Romans, 1939) says that the novel keeps its distance from 
things and by its very nature is distanced from them; it 'hovers' over them, and 'smiles down upon them'.

(Cuddon 1999: 431)

It can be concluded that, not surprisingly, postmodern theory in all three forms of artistic expression - literature, visual art and music - shares the same artistic techniques (playfulness, humor and irony), and with the same aim. The ironic detachment which permeates these works puts into question our individual visions of human beings and existence. The element of humor is used to express the insensitivity, absurdity and paradox of the modern world. They are both 'detached' ways of speaking in a postmodern world where "no utopian possibility of change is left untouched by irony and skepticism" (Stacey 2010: 44). Through this type of analysis, Booth has led us into a pattern of reconstructions of a variety of tones and voices, enabling us to deal, at the theoretical level at least, with the irony and absurdity of the human condition.

\section{References}

Baldick, C. (1996). Oxford Concise Dictionary of Literary Terms. Oxford: Oxford University Press.

Booth, W. C. (1974). A Rhetoric of Irony. Chicago and London: University of Chicago Press.

Cuddon, J. A. (1999). The Penguin Dictionary of Literary Terms and Literary Theory. London: Penguin Books.

Eco, U. (1985). Reflections on the Name of the Rose. Encounter LXIV, 719.

Frye, H. N. (1957). Anatomy of Criticism: Four Essays. Princeton: Princeton University Press.

Heller, J. (1961). Catch-22. New York: Simon \& Schuster.

Heller, J. (1994). Catch-22. New York: Simon \& Schuster.

Kramer, J. (2002). The Nature and Origins of Musical Postmodernism. In: Lochhead J. and Aunder J. (eds.), Postmodern Music/Postmodern Thought. New York/London: Routledge, 207-239.

McEvilly, T. in Richard R. et al. (1998). Beauty Is Nowhere: Ethical Issues in Art and Design. New York/London: Routledge.

Muecke, D. C. (1969). The Compass of Irony. New York/London: Routledge. 
Mirjana M. Knežević Postmodern irony and humor in Catch-22 by Joseph Heller and their ...

Reed, P. (1999). Kurt Vonnegut's Fantastic Faces. Journal of the Fantastic in the Arts, Volume 10, Issue No. 1, 77-87.

Sim, S. (2001). The Routledge Companion to Postmodernism. New York/ London: Routledge.

Stacey, R. D. (2010). Reading the Postmodern: Canadian Literature and Criticism After Modernism. Otawa: University of Ottawa Press.

Vonnegut, K. (1999). Palm Sunday: An Autobiographical Collage. New York: The Dial Press.

Vonnegut, K. 2009. Quotes. http://www.quotationspage.com

Wharton, E. (1972). A Backward Glance: The Autobiography of Edith Wharton. London: Constable.

Received: 15 June 2011

Accepted for publication: 10 September 2011

\section{Мирјана Кнежевић}

ПОСТМОДЕРНА ИРОНИЈА И ХУМОР У РОМАНУ КВАКА-22

ЏОЗЕФА ХЕЛЕРА И ЊИХОВЕ ПАРАЛЕЛЕ У ПОСТМОДЕРНОЈ

МУЗИЦИ И ЛИКОВНОЈ УМЕТНОСТИ

\section{Сажетак}

Есеј истражује концепт ироније и начине на које се овај концепт одражава у тако различитим облицима естетског израза као што су књижевна, музичка и ликовна уметност, посебно у оквиру постмодерног доба које не само прихвата, него и интензивира и утиче на ову давно установљену стилску технику. Са овим циљем, есеј анализира роман Џозефа Хелера Квака-22 као репрезентативан пример постмодерне књижевности, као и графику Курта Вонегата Трауm у Кохоузу, песму Руперта Холмса Пина колада и композицију Лироја Андерсона Мачка која игра валцер као одговарајуће примере у ликовној уметности и музици. Теоријски оквир се заснива на концепту ироније Вејна Бута, а такође укључује и хумор као пратећи елемент ироничног израза.

Кључне речи: иронија, хумор, постмодернизам, Џозеф Хелер, Квака-22, Вејн Бут 